\title{
Groundwater Quality and Its Impact on Health: A Preliminary Evaluation of Dental Fluorosis in Julimes, Chihuahua, Mexico
}

\author{
Aida Verónica Ontiveros-Terrazas, Alejandro Villalobos-Aragón*, \\ Vanessa Verónica Espejel-García, Daphne Espejel-García \\ Facultad de Ingeniería, Universidad Autónoma de Chihuahua, Chihuahua, México \\ Email: *avillalobos@uach.mx
}

How to cite this paper: Ontiveros-Terrazas, A.V., Villalobos-Aragón, A., Espejel-García, V.V. and Espejel-García, D. (2020) Groundwater Quality and Its Impact on Health: A Preliminary Evaluation of Dental Fluorosis in Julimes, Chihuahua, Mexico. Journal of Water Resource and Protection, 12, 545-557. https://doi.org/10.4236/jwarp.2020.127033

Received: May 26, 2020

Accepted: July 3, 2020

Published: July 6, 2020

Copyright $\odot 2020$ by author(s) and Scientific Research Publishing Inc. This work is licensed under the Creative Commons Attribution International License (CC BY 4.0)

http://creativecommons.org/licenses/by/4.0/

\begin{abstract}
Medical Geology can be defined as the branch of geology dealing with the relationship between natural geological aspects and health in organisms (humans and animals), trying to determine the influence of ordinary environmental factors on the geographical distribution of health issues. The main goals of this research were: 1) to evaluate the severity of dental fluorosis (DF) and fluoride concentration in groundwater, used for human consumption, as an indicator of overexposure to fluorides, 2) to estimate the Community Fluorosis Index (CFI) in the Julimes municipality in Chihuahua, Mexico. Nine water samples were collected in four locations in the Julimes area: Hacienda Humboldt, La Regina, Colonia San Jose, and Julimes. Samples were collected and stored in accordance with the Mexican standard (NOM-014-SSA1-1993). All the samples exceeded the maximum permissible limit established in the modified Mexican standard (NOM-127-SSA1-1994) of $1.5 \mathrm{mgL}^{-1}$ for fluoride in water for human consumption. Average concentrations of $2.74 \mathrm{mgL}^{-1}$ were found in Colonia San Jose, $2.19 \mathrm{mgL}^{-1}$ in La Regina, $2.17 \mathrm{mgL}^{-1}$ in Julimes and $2.06 \mathrm{mgL}^{-1}$ in Hacienda Humboldt. Dental Fluorosis diagnosis was evaluated using the Dean Index and the CFI applied to residents. A total of 100 inhabitants were examined, with interviews and oral examinations also carried out. Dental Fluorosis prevalence was $92 \%$ overall for the municipality, while for Colonia San Jose was of $100 \%$, of $88.89 \%$ for Hacienda Humboldt, 88.24\% for Julimes and 96\% for La Regina. Dental Fluorosis' severity for the Julimes municipality was distributed as follows: $2 \%$ normal, $6 \%$ questionable, $8 \%$ very mild, $13 \%$ mild, $19 \%$ moderate, and $52 \%$ severe. An average CFI was found for the four localities of 3.02 points, with a very notable impact on public health.
\end{abstract}




\section{Keywords}

Dental Fluorosis, Dean Index, Community Fluorosis Index, Chihuahua

\section{Introduction}

Groundwater is one of the main reserves of drinking water in the world, but due to the geological materials where it is located, some chemical elements and inorganic compounds, potentially harmful to the health of organisms, are dissolved in it, such as arsenic and fluoride. Arsenic and fluoride are present in groundwater in several Latin American countries such as Mexico, Argentina and Chile, mainly in arid and semi-arid regions [1]. Mexican regulations establish a maximum permissible concentration of $1.5 \mathrm{mgL}^{-1}$ of fluoride in public water supply [2] and $0.7 \mathrm{mgL}^{-1}$ as maximum allowable for bottled water [3].

In Mexico, it has been estimated that around five million people are affected by fluoride ingestion in groundwater [4]. Since 1973, it was reported that at least 19 communities in the states of Aguascalientes, Baja California Norte, Chihuahua, Durango, Jalisco, Sonora and Tamaulipas, had natural fluoride concentrations in drinking water above the optimum level of 0.7 to $1.5 \mathrm{mgL}^{-1}$ as mentioned before [5]. Subsequently, studies were included in Aguascalientes, Baja California, Durango, Chihuahua, Jalisco, San Luis Potosi, Campeche, and Mexico City, in which it was concluded that in areas with natural fluoride in the water, prevalence of fluorosis ranged from $30 \%$ to $100 \%$ [6].

In Chihuahua, northern Mexico, contamination by fluoride dissolved in groundwater destined for human consumption is nowadays considered to be an endemic problem. Several studies have been conducted, revealing high concentrations of fluoride in groundwater within the Casas Grandes, El Sauz-Encinillas, Tabalaopa-Aldama, Meoqui-Delicias and Jimenez-Camargo aquifers [7].

Previous work [8] collected water samples in the south-central region of the state of Chihuahua, including its capital, Chihuahua city, as well as localities of 13 municipalities (Aldama, Camargo, Chihuahua, Coronado, Delicias, Jimenez, Julimes, La Cruz, Meoqui, Rosales, San Francisco de Conchos, Saucillo and Satevo). Fluoride levels within water samples ranged between 0.05 to $11.8 \mathrm{mgL}^{-1}$. Concentrations greater than $1.5 \mathrm{mgL}^{-1}$, were found in $37.2 \%$ of the water samples, while $30.9 \%$ ranged between 0.5 and $1.0 \mathrm{mgL}^{-1}$, and $13.8 \%$ of the samples contained a concentration lower than the norm. Another author [9] reported fluoride concentrations ranging from $1.45 \mathrm{mgL}^{-1}$ to $6.49 \mathrm{mgL}^{-1}$ for the Flores Magon-Villa Ahumada aquifer, represented by the San Lorenzo and Ahumada localities, respectively. Also reported values ranging from $2.78 \mathrm{mgL}^{-1}$ to $7.5 \mathrm{mgL}^{-1}$ in the La Vieja aquifer, in the Pestañas and Ojo Caliente towns. While for the Buenaventura aquifer, concentrations vary from 1.8 to $5.44 \mathrm{mgL}^{-1}$, in the Barrio de las Flores and Buenaventura and lastly, for Casas Grandes' aquifer concentrations fluctuate from 0.46 to $8.5 \mathrm{mgL}^{-1}$ in the Juarez Colony and the city of Nuevo Casas Grandes. 
In the Meoqui-Delicias' aquifer (Figure 1), several drinking water quality problems are related to high concentrations of dissolved solids, arsenic, fluoride, sulfates, nitrates, plus other important health constituents [10]. It is one of the most problematic aquifers in the state of Chihuahua, due to the presence of fluoride, exceeding the established limit, and present mainly in sediments (alluvium and polymictic conglomerates), surrounded by Tertiary rhyolitic rocks, outcropping in the La Boquilla, Alta, Humboldt, Chuecos, Los Pozos, Tortuguillas, El Borrego and Las Virgenes' ranges [7].

Fluoride produces adverse effects for the organisms, when ingested in high concentrations, like dental fluorosis (DF), and in prolonged expositions can produce osseous fluorosis (OF). Metabolic changes have been reported in the soft tissues such as: thyroid, brain, reproductive organs, kidneys, and liver [11]. Dental fluorosis is defined as a hypo-mineralization of tooth enamel, characterized by large superficial and subsurface porosities, greater than those found in normal enamel, due to excessive intake of fluorides during the period of dental development, specifically in the first five years of life [12].

Clinically this alteration is characterized by the presence of opaque whitish areas or striae, and in its more intense degrees, can display a brownish coloration caused by extrinsic pigments, until loss of a large part of the enamel produced by a severe hypoplasia that can modify the shape of the tooth [13]. The severity of this disease is related to the concentration of fluoride ingested, the period of intake, and individual susceptibility, which may depend on risk factors such as calcium deficiency disorders, malnutrition, and kidney problems [14].

Currently, the Dean Index is the most used scale for the diagnosis and classification of dental fluorosis [15]. The criteria for the classification system of the dental fluorosis index developed by Dean in 1934, was based on seven points of ordinal scale (normal, questionable, very mild, mild, moderate, moderately severe, and severe). However, it was updated in 1942, still currently used, and consists of six points of ordinal scale (normal, questionable, very mild, mild, moderate, and severe) [16] as seen in Table 1.

Table 1. Dean dental fluorosis index.

\begin{tabular}{lll}
\hline Classification & Key & Criteria \\
Normal & 0 & The surface of the enamel is soft, shiny and usually pale cream white. \\
Questionable & 1 & $\begin{array}{l}\text { The enamel shows slight alterations of the translucency of the normal } \\
\text { enamel, which can vary between some white spots and scattered spots. } \\
\text { Small areas, white as paper and opaque, irregularly scattered on the } \\
\text { tooth, but affecting less than } 25 \% \text { of the labial tooth surface. }\end{array}$ \\
Mery Mild & 2 & $\begin{array}{l}\text { The white opacity of the enamel is greater than that corresponding to the } \\
\text { key } 2 \text {, but it covers less than } 50 \% \text { of the tooth surface. } \\
\text { The enamel surfaces of the teeth show marked wear; In addition, brown } \\
\text { dye is often a feature that alters the appearance of the tooth. } \\
\text { The surface of the enamel is greatly affected, and hypoplasia is so marked } \\
\text { that the general shape of the tooth can be affected. Excavated or worn } \\
\text { areas are present and an extended brown tint is found; the teeth often } \\
\text { have a corroded appearance. }\end{array}$ \\
& 5 &
\end{tabular}




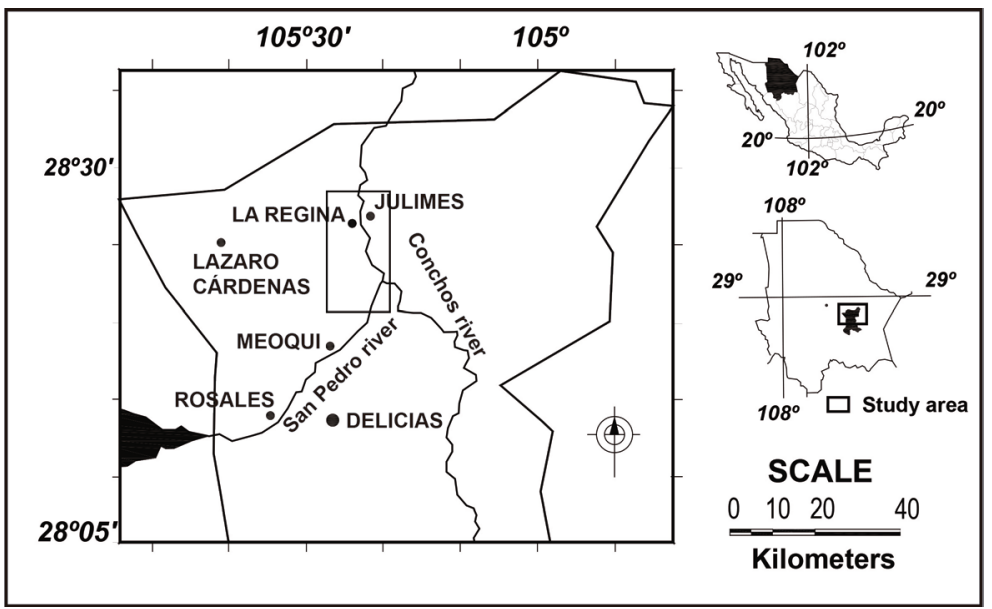

Figure 1. Location map of the studied area.

To determine the severity of dental fluorosis as a public health problem, Dean designed a method for calculating the severity of fluorosis in a community called the Community Fluorosis Index (CFI) [16]. To obtain the CFI there is a weight (p) determined for each degree of severity of the Dean index (Table 2) that specifies the following values [13].

The Community Fluorosis Index (CFI) was calculated by using the following formula:

$$
\text { Community Fluorosis Index }=\frac{\sum \text { individuals with fluorosis } \times \text { ponderation }}{\text { Total number of exmined individuals }}
$$

Once the CFI was calculated, the criteria for scoring and relevance for public health was determined based according to values [16] displayed in Table 3.

For the CFI interpretation, Dean indicates that, if it exceeds the value of 0.6 , it begins to constitute a public health problem [13]. The proportion of patients with dental fluorosis in the Mexican Health Services, for Chihuahua was of 10\% [17]. In the review of the prevalence of dental fluorosis in Mexico, a high prevalence of dental fluorosis was reported in Chihuahua. In addition, these researchers analyzed 61 sources of tap water.

Previous reports had indicated that the fluoride contained in tap water varied from 0 to $3 \mathrm{ppm}$ in Chihuahua City and from $0.1 \mathrm{ppm}$ to $10 \mathrm{ppm}$ in other communities of the state. In this study, fluoride content of tap water was reported at high levels. The prevalence was $76.2 \%$, of which $23.1 \%$ was classified as severe dental fluorosis, with a range of fluoride contained in water from 0.12 to 2.36 ppm in individuals aged 10 to 12 years in a study conducted in 1992 [5].

In Delicias, records of dental fluorosis indexes were made according to the Thylstrup and Fejerskov (TF) international classification [18]. The goal was to evaluate, analyze and compare the different degrees of dental fluorosis among children of 5th and 6th grade (elementary school), through 109 dental check-ups in children of different primary schools within the city. Results showed degrees of dental fluorosis ranged from TF-0 to TF-7 [18]. 
Table 2. Community Fluorosis Index ponderation.

\begin{tabular}{ccc}
\hline Classification & Key & Ponderation $^{\mathrm{a}}$ \\
\hline Normal & 0 & 0 \\
Questionable & 1 & 0.5 \\
Very Mild & 2 & 1 \\
Mild & 3 & 2 \\
Moderate & 4 & 3 \\
Severe & 5 & 4 \\
\hline
\end{tabular}

a. Adapted from the Health Ministry. Undersecretary of Health Prevention and Promotion. National Center for Epidemiological Surveillance and Disease Control. Oral Health Subdirectorate. Manual for the Use of dental fluorides in the Mexican Republic. Mexico (DOF, 2003).

Table 3. Community Fluorosis Index ponderation relatively to public health [16].

\begin{tabular}{cc}
\hline CFI value & Relevance for public health $^{\mathrm{a}}$ \\
\hline $0.0-0.4$ & Negative \\
$0.4-0.6$ & In the limit \\
$0.6-1.0$ & Mild \\
$1.0-2.0$ & Medium \\
$2.0-3.0$ & Notable \\
$3.0-4.0$ & Highly notable \\
\hline
\end{tabular}

a. Adapted from Hiremath (2011). Textbook of Preventive and Community Dentistry.

\section{Methodology}

The study was carried out in three stages:

1) The first stage was selecting the study area (Julimes, Chihuahua), due to the high concentrations of fluorine in the Meoqui-Delicias' aquifer reported previously [7] [10] and to hydrothermalism in the area [9], the fluorine-rich groundwater is found mainly in areas with this property.

2) The second stage of the process consisted in the selection of four locations in the municipality of Julimes, Chihuahua. The selected localities were: Julimes, La Regina, Colonia San Jose, and Hacienda Humboldt.

3) In the third stage, Dental Fluorosis diagnosis was evaluated using the Dean Index and the Community Fluorosis Index (CFI) applied to residents in the 4 selected locations. A total of 100 inhabitants were examined, with interviews and oral examinations also carried out. Participants older than 12 years old from each locality were randomly selected, who were contacted at their home. Inclusion criteria consisted of: a) being 12 years of age or older; b) population of both genders; c) having lived since his birth in the municipality of Julimes; d) not have had any orthodontic treatment during his life; and e) having signed the consent document.

A total of nine well water samples were collected in the La Regina, Julimes, Hacienda Humboldt y Colonia San Jose, and Julimes locations (Figure 2). 
Water samples were collected and stored according to the indications of the NOM-014-SSA1-1993, using $333 \mathrm{ml}$ plastic bottles and ice for their conservation. Sampling was conducted on June 22, 2016 and analyzes conducted from June 24 to July 4, 2016. The analysis of the data obtained from the drinking water samples were made by comparing the maximum permissible limits in the NOM-127-SSA1-1994.

Dental check-ups were carried out on subjects over 12 years of age in four localities of Julimes' municipality: Julimes, La Regina, Colonia San Jose, and Hacienda Humboldt. For the examination of the individual natural light was used, placing the person so that he received maximum illumination. Teeth were dried with rolls of cotton, and next a picture of his front teeth was taken.

Dental Fluorosis Index (DFI) records for each study subject were obtained by observing all the dental organs present, it is based on the two most affected teeth that, in case of not having the same severity, the degree corresponding to the least affected should be recorded. In case of doubt, the lowest degree should be given [15].

The Community Fluorosis Index (CFI) in population was also calculated according to the number of individuals affected by the statistical weighting divided by the total number of individuals examined; the results are expressed in averages which were interpreted under the CFI scoring criteria and their public health relevance. Dental fluorosis determination was carried out from May to October 2016. The sample size was calculated using the statistical formula for qualitative variables in populations under 10,000 subjects. It guaranteed an error in the estimates no greater than $10 \%$, with a confidence level of $95 \%$.

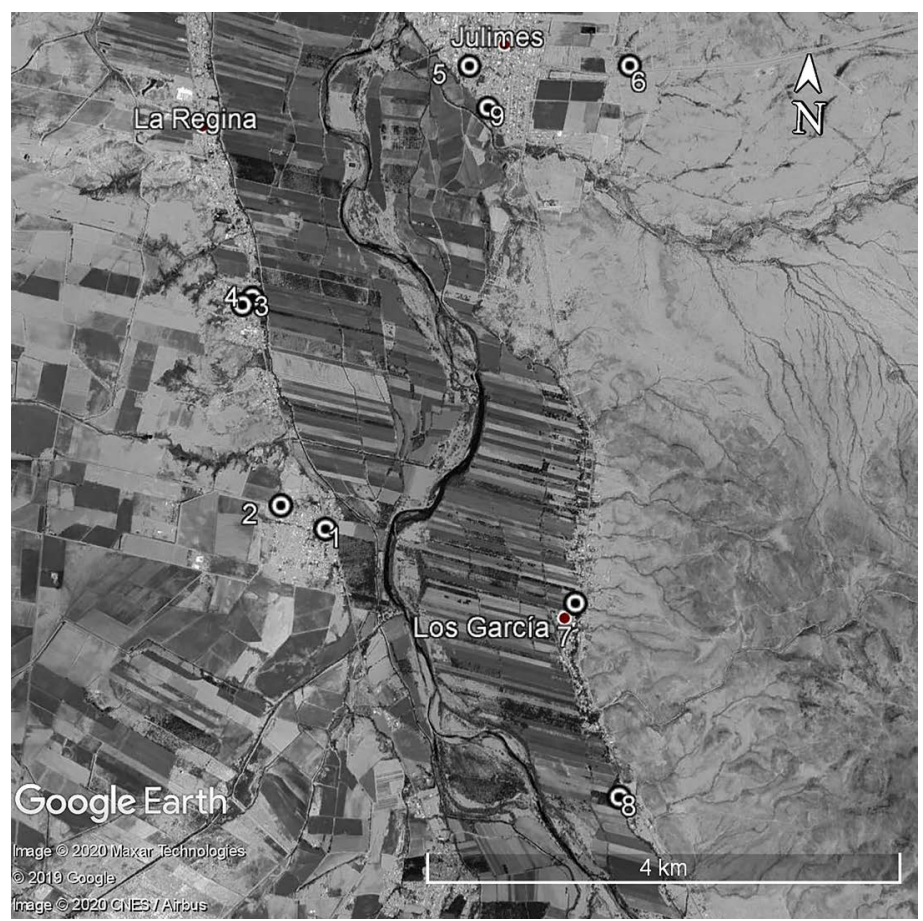

Figure 2. Sampling sites in the Julimes region [19]. 


\section{Results}

\subsection{Hydrogeochemical Data}

Table 4 lists the maximum permissible values as well as the concentrations of the different hydrogeochemical parameters obtained for each of the samples, classified by location. The values of the different parameters that exceeded the maximum permissible limit established in the modification to the Official Mexican Standard NOM-127-SSA1-1994 [2] are shown in bold.

Water samples were classified as sulfate-sodic waters. The possible origin of this water family can be linked to the presence of evaporite materials and the possibility of ion exchange reactions with the clays present in the alluvial fill.

All the water samples $(n=9)$ went above the maximum allowable limit of $1000 \mathrm{mgL}^{-1}$ for Total Dissolved Solids (TDS). The highest concentration of 2150 $\mathrm{mgL}^{-1}$ corresponds to a sample of well water from Julimes and the lowest of 1012 $\mathrm{mgL}^{-1}$ to a sample of tap water from the same locality. Sulfates $\left(\mathrm{SO}_{4}\right)$ are present in water samples from the localities of the study area in concentrations ranging between 348.30 and $599.34 \mathrm{mgL}^{-1}$. The $77.78 \%(\mathrm{n}=7)$ of the samples went over the maximum permissible limit established by the standard of $400 \mathrm{mgL}^{-1}$.

Regarding the arsenic levels in the water samples collected, it was identified that $100 \%(\mathrm{n}=9)$ surpassed the maximum limit allowed by NOM-127-SSA1-1994 of $0.025 \mathrm{mgL}^{-1}$. The highest concentration of arsenic corresponds to the well water sample in Colonia San Jose with $0.195 \mathrm{mgL}^{-1}$, followed by a concentration of 0.169 $\mathrm{mgL}^{-1}$ of the tap water sample from the same locality. The values of all the samples vary between 0.065 to $0.195 \mathrm{mgL}^{-1}$. All the samples exceeded the maximum permissible limit established in the Mexican standard (NOM-127-SSA1-1994) of $1.5 \mathrm{mgL}^{-1}$ for fluorides in water for human consumption. Average concentrations of $2.74 \mathrm{mgL}^{-1}$ were found in Colonia San Jose, $2.19 \mathrm{mgL}^{-1}$ in La Regina, 2.17 $\mathrm{mgL}^{-1}$ in Julimes and $2.06 \mathrm{mgL}^{-1}$ in Hacienda Humboldt.

\subsection{Dental Fluorosis Determination}

A total of 100 dental check-ups and interviews were performed to residents over 12 years of age in the Julimes, Colonia San Jose, La Regina, and Hacienda Humboldt in the municipality of Julimes, Chihuahua. 33\% ( $n=33$ cases) were of the female gender and $67 \%(\mathrm{n}=67$ cases) of the male gender (Table 5).

The average age was 38.13 years. Being the group of 21 to 30 years the one that appeared with greater frequency (Table 6).

Dental Fluorosis prevalence was $92 \%(n=92) .100 \%(n=15)$ of Colonia San Jose presented dental fluorosis, $88.89 \%(\mathrm{n}=8)$ of the locality Hacienda Humboldt, $88.24 \%(\mathrm{n}=45)$ of Julimes, and $96 \%(\mathrm{n}=24)$ in La Regina (Table 7).

Dental fluorosis in the 4 communities was distributed as follows: $2 \%(n=2)$ normal, $6 \%(\mathrm{n}=6)$ questionable, $8 \%(\mathrm{n}=8)$ very mild, $13 \%(\mathrm{n}=13)$ mild, $19 \%$ $(\mathrm{n}=19)$ moderate and severe with $52 \%(\mathrm{n}=52)$. See Table 8 for DF frequency and gender distribution. 
Table 4. Chemical analytical results of water samples collected.

\begin{tabular}{|c|c|c|c|c|c|c|c|c|c|c|}
\hline \multirow{2}{*}{ Parameter } & \multirow{2}{*}{$\begin{array}{c}\text { NOM } \\
127\end{array}$} & \multicolumn{9}{|c|}{ Sample } \\
\hline & & 1 & 2 & 3 & 4 & 5 & 6 & 7 & 8 & 9 \\
\hline Latitude & - & 28.38 & 28.38 & 28.40 & 28.40 & 28.42 & 28.42 & 28.37 & 28.36 & 28.41 \\
\hline Longitude & - & -105.43 & -105.44 & -105.44 & -105.44 & -105.42 & -105.41 & -105.41 & -105.41 & -105.42 \\
\hline $\mathrm{pH}$ & $6.5-8.5$ & 7.77 & 7.52 & 7.46 & 7.34 & 8.36 & 7.64 & 7.62 & 7.63 & 7.66 \\
\hline $\mathrm{CO}_{3}$ & - & 0 & 0 & 0 & 0 & 3.42 & 0 & 0 & 0 & 0 \\
\hline $\mathrm{HCO}_{3}$ & - & 510.22 & 253.11 & 476.21 & 506.82 & 132.6 & 258.51 & 340.15 & 333.35 & 244.91 \\
\hline $\mathrm{Na}$ & 200 & 571.1 & 525.3 & 480.6 & 498.7 & 180.7 & 265.5 & 173 & 182.3 & 185.2 \\
\hline K & - & 2.37 & 1.54 & 6.73 & 6.65 & 10.52 & 11.49 & 7.71 & 7.96 & 11.22 \\
\hline $\begin{array}{c}\text { Total } \\
\text { alkalinity }\end{array}$ & - & 418.22 & 209.11 & 390.3 & 415.43 & 108.74 & 211.9 & 278.81 & 273.23 & 200.74 \\
\hline TDS & 1000 & 1570 & 1540 & 1660 & 1690 & 1012 & 1254 & 1178 & 1168 & 2150 \\
\hline $\mathrm{SO}_{4}$ & 400 & 348.29 & 453.29 & 599.34 & 565.75 & 373.04 & 490.61 & 421.66 & 436.69 & 412.82 \\
\hline $\mathrm{Cl}$ & 250 & 171.39 & 235.22 & 199.73 & 209.84 & 67.93 & 88.21 & 67.93 & 57.79 & 62.86 \\
\hline $\mathrm{Ca}$ & - & 93.96 & 48.98 & 124.1 & 125.5 & 103.8 & 132 & 148.7 & 151.7 & 112 \\
\hline $\mathrm{Mg}$ & - & 16.5 & 3.74 & 16.6 & 16.7 & 12.24 & 14.74 & 23.63 & 22.99 & 16.93 \\
\hline As & 0.025 & 0.169 & 0.195 & 0.101 & 0.104 & 0.1 & 0.111 & 0.065 & 0.067 & 0.104 \\
\hline $\mathrm{F}$ & 1.5 & 3.17 & 2.3 & 2.2 & 2.17 & 2.18 & 2.16 & 2.06 & 2.06 & 2.18 \\
\hline
\end{tabular}

Note: All the parameters are measured in $\mathrm{mgL}^{-1}$, except Total Alkalinity and $\mathrm{pH}$.

Table 5. Gender distribution of surveyed subjects in the study.

\begin{tabular}{cccc}
\hline & \multicolumn{2}{c}{ Gender } & \\
\cline { 2 - 3 } Locality & Female & Male & Total \\
\cline { 2 - 3 } & $\mathbf{n}$ & $\mathbf{n}$ & \\
Colonia San Jose & 6 & 9 & 15 \\
Hacienda Humboldt & 4 & 5 & 9 \\
Julimes & 16 & 35 & 51 \\
La Regina & 7 & 18 & 25 \\
Total & 33 & 67 & 100
\end{tabular}

Table 6. Gender distribution of surveyed subjects in the study.

\begin{tabular}{ccc}
\hline Age range (years) & $\mathbf{n}$ & \% \\
\hline $12-20$ & 17 & 17 \\
$21-30$ & 28 & 28 \\
$31-40$ & 8 & 22 \\
$41-50$ & 22 & 17 \\
$51-60$ & 17 & 5 \\
$61-70$ & 5 & 3 \\
$>70$ & 3 & 100 \\
\hline
\end{tabular}


Table 7. Dental Fluorosis prevalence according to each studying site.

\begin{tabular}{|c|c|c|c|c|c|c|c|c|c|c|}
\hline \multirow{3}{*}{ Criteria } & \multicolumn{8}{|c|}{ Localities } & \multirow{2}{*}{\multicolumn{2}{|c|}{ Total }} \\
\hline & \multicolumn{4}{|c|}{ Colonia San Jose Hacienda Humboldt } & \multicolumn{2}{|c|}{ Julimes } & \multicolumn{2}{|c|}{ La Regina } & & \\
\hline & $\%$ & $\mathbf{n}$ & $\%$ & $\mathbf{n}$ & $\%$ & $\mathbf{n}$ & $\%$ & $\mathbf{n}$ & $\%$ & $\mathbf{n}$ \\
\hline Normal & 0.00 & 0 & 0.00 & 0 & 3.92 & 2 & 0 & 0 & 2 & 2 \\
\hline Questionable & 0.00 & 0 & 11.11 & 1 & 7.84 & 4 & 4 & 1 & 6 & 6 \\
\hline Very Mild & 6.67 & 1 & 11.11 & 1 & 5.88 & 3 & 12 & 3 & 8 & 8 \\
\hline Mild & 20.00 & 3 & 0.00 & 0 & 13.73 & 7 & 12 & 3 & 13 & 13 \\
\hline Moderate & 6.67 & 1 & 11.11 & 1 & 21.57 & 11 & 2 & 6 & 19 & 19 \\
\hline Severe & 66.67 & 10 & 66.67 & 6 & 47.06 & 24 & 48 & 12 & 52 & 52 \\
\hline Total & 100.00 & 15 & 100.00 & 9 & 100.00 & 51 & 100 & 25 & 100 & 100 \\
\hline DF prevalence & 100 & 15 & 88.89 & 8 & 88.24 & 45 & 96 & 24 & 92 & 92 \\
\hline
\end{tabular}

Table 8. Dental Fluorosis (DF) prevalence by gender in the study sites.

\begin{tabular}{|c|c|c|c|c|c|c|}
\hline \multirow{3}{*}{ Criteria } & \multicolumn{4}{|c|}{ Gender } & \multirow{2}{*}{\multicolumn{2}{|c|}{ Total }} \\
\hline & \multicolumn{2}{|c|}{ Female } & \multicolumn{2}{|c|}{ Male } & & \\
\hline & $\%$ & $\mathbf{n}$ & $\%$ & $\mathbf{n}$ & $\%$ & $\mathbf{n}$ \\
\hline Normal & 3.92 & 2 & 0 & 0 & 2 & 2 \\
\hline Questionable & 7.84 & 4 & 4 & 1 & 6 & 6 \\
\hline Very Mild & 5.88 & 3 & 12 & 3 & 8 & 8 \\
\hline Mild & 13.73 & 7 & 12 & 3 & 13 & 13 \\
\hline Moderate & 21.57 & 11 & 2 & 6 & 19 & 19 \\
\hline Severe & 47.06 & 24 & 48 & 12 & 52 & 52 \\
\hline Total & 100.00 & 51 & 100 & 25 & 100 & 100 \\
\hline DF prevalence & 88.24 & 45 & 96 & 24 & 92 & 92 \\
\hline
\end{tabular}

As seen in Table 9, a prevalence of dental fluorosis of $100 \%$ was found in individuals with an age range of 31 to 40 years $(n=8), 61$ to 70 years $(n=5)$ and older than 70 years $(n=3)$. The $95.46 \%(n=21)$ of subjects in the age range of 41 to 50 years presented dental fluorosis, $94.12 \%(n=16)$ from 51 to 60 years. The lowest prevalence was in the age ranges of 21 to 30 years and 12 to 20 years with $92.86 \%(\mathrm{n}=26)$ and $76.48 \%(\mathrm{n}=13)$, respectively.

The CFI for the four localities corresponds to 3.02 points, with a very notable effect on public health [16]. The most affected localities were Colonia San Jose with 3.33 points, Hacienda Humboldt with 3.16, followed by La Regina with 3.06 points and the town of Julimes with 2.90 .

The CFI by age range in Table 9 and Figure 3, displays that the groups most affected are: the one that corresponds to people over 70 with a score of 3.67 ; individuals in an age range between 61 and 70 with a CFI of 3.4, followed by the group of 51 to 60 years old with a CFI of 3.33, the age range from 31 to 40 years with 3.25 and the age group of 41 to 50 years with 3.15. A lower degree of CFI was observed in people belonging to the age groups of 12 to 20 years and 21 to 30 years with a CFI of 2.44 and 2.91 , respectively. 


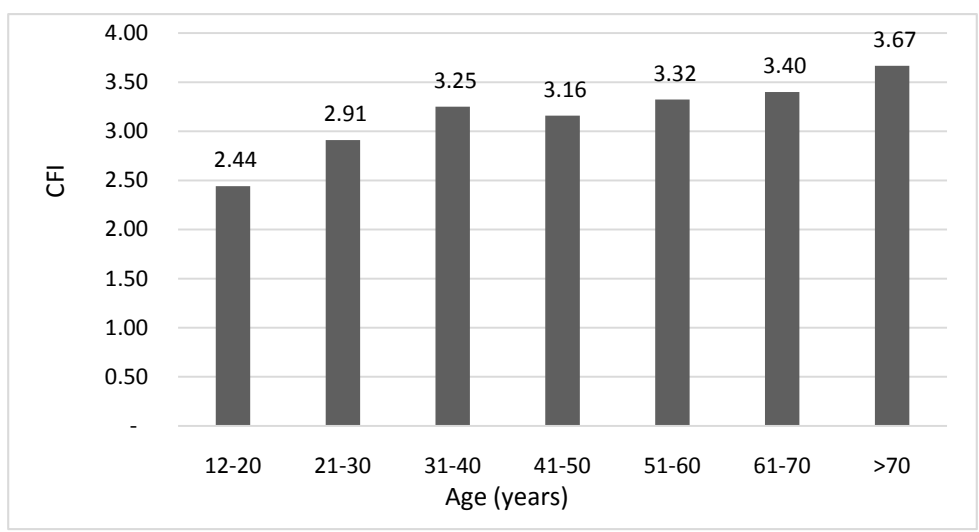

Figure 3. The Community Fluorosis Index for different age distribution.

Table 9. Gender distribution of surveyed subjects in the study.

\begin{tabular}{|c|c|c|c|c|c|c|c|c|c|c|c|c|c|c|c|c|}
\hline \multirow{3}{*}{ Criteria } & \multicolumn{16}{|c|}{ Age range (years) } \\
\hline & \multicolumn{2}{|c|}{$12-20$} & \multicolumn{2}{|c|}{$21-30$} & \multicolumn{2}{|c|}{$31-40$} & \multicolumn{2}{|c|}{$41-50$} & \multicolumn{2}{|c|}{$51-60$} & \multicolumn{2}{|c|}{$61-70$} & \multicolumn{2}{|c|}{$>70$} & \multicolumn{2}{|c|}{ Total } \\
\hline & $\mathbf{n}$ & $\%$ & $\mathrm{n}$ & $\%$ & $\mathbf{n}$ & $\%$ & $\mathrm{n}$ & $\%$ & $\mathrm{n}$ & $\%$ & $\mathbf{n}$ & $\%$ & $\mathbf{n}$ & $\%$ & $\mathrm{n}$ & $\%$ \\
\hline Normal & 5.8 & 1 & 3.5 & 1 & 0.0 & 0 & 0.0 & 0 & 0.0 & 0 & 0 & 0 & 0 & 0 & 2 & 2 \\
\hline Questionable & 17.6 & 3 & 3.5 & 1 & 0.0 & 0 & 4 & 1 & 5.8 & 1 & 0 & 0 & 0 & 0 & 6 & 6 \\
\hline Very Mild & 11.7 & 2 & 3.5 & 1 & 12.5 & 1 & 12 & 3 & 17.6 & 3 & 0 & 0 & 0 & 0 & 8 & 8 \\
\hline Mild & 17.6 & 3 & 17.8 & 5 & 12.5 & 1 & 12 & 3 & 5.8 & 1 & 0 & 0 & 0. & 0 & 13 & 13 \\
\hline Moderate & 0.0 & 0 & 35.7 & 10 & 12.5 & 1 & 24 & 6 & 5.8 & 1 & 0 & 0 & 33.3 & 1 & 19 & 19 \\
\hline Severe & 47.0 & 8 & 35.7 & 10 & 62.5 & 5 & 48 & 12 & 64.7 & 11 & 100 & 5 & 66.6 & 2 & 52 & 52 \\
\hline Total & 100 & 17 & 3.5 & 1 & 100 & 8 & 100 & 25 & 100 & 17 & 100 & 5 & 100 & 3 & 100 & 100 \\
\hline $\begin{array}{c}\mathrm{DF} \\
\text { prevalence }\end{array}$ & 100 & 15 & 88.8 & 8 & 88.2 & 45 & 96 & 24 & 92 & 92 & & & & & & \\
\hline
\end{tabular}

As stated by gender, women had a lower CFI (2.61), while men had 3.24. According to the ranges established [13] for the CFI interpretation, if this exceeds the value of 0.6 is considered a public health problem, in all cases this criterion is surpassed. Considering the ranges of CFI [16], the degrees of affectation to public health are the highest in the scale, being a notable affectation those values of CFI that are in the range of 2.1 to 3.0 and those values which are in the range of 3.1 to 4.0 is a very significant effect on public health.

\section{Conclusions}

The analysis of fluorides in the area revealed that $100 \%$ of the collected samples surpassed the normed value of $1.5 \mathrm{mgL}^{-1}$ established in the Mexican drinking water standard (NOM 127-SSA-1994), being the most affected sites La Regina and Colonia San Jose, in Julimes, Chihuahua, Mexico. Likewise, all the samples analyzed for arsenic also exceeded the maximum limit of $0.025 \mathrm{mgL}^{-1}$ established by the Mexican norm. The presence of fluoride and arsenic in the water is attributed to the presence of clays formed by the weathering of rhyolitic composition 
rocks (mostly tuffs) in the area. The water families are due either to evaporitic materials in playa lake-conditions within the soils, or probably to ion exchange reactions within the clays.

The general prevalence of fluorosis in the municipality was $92 \%$. This number places it as a public health problem for the Municipal and State government. A score of 3.02 was obtained with a serious level of public health significance. There is a decrease in the CFI score with respect to the age groups, being the least affected individuals between 12 and 20 years with a score of 2.44. People over 70 years of age obtained an CFI score of 3.67. This can be attributed to the existence of systems for the demineralization of drinking water established in the area during the last decade by government, helping to prevent effects that fluoride can cause on the population health, considering that dental fluorosis can only be produced during the first eight years of life. The ICF according to gender had a significant difference, women obtained a score of 2.61 and men of 3.24. The most affected localities according to the CFI were Colonia San Jose with 3.33 points, Hacienda Humboldt with 3.16, followed by La Regina with 3.06 points and the town of Julimes with 2.90 .

The results of this research express the concentrations of fluoride and arsenic in groundwater, as well as the impact of fluoride on the health of the population, which should be considered by decision makers to prevent possible health risks related to the presence of both arsenic and fluorides in drinking water. Hopefully obtained results can be used as a tool to elaborate short and midterm health policies, such as corrective and preventive oral health programs, and overall to improve the quality of life of the inhabitants of the Julimes region.

It is recommended to include the municipality of Julimes into the Mexican official list of areas where fluorinated iodized salt should not be marketed, due to the high concentrations of fluoride in the supply water, with the aim of restricting the distribution, use and consumption of fluoride, together to the use of toothpaste, which, as reported in the literature review, are additional sources of fluorides.

\section{Authors' Contributions}

A.V.O.T. and A.V.A. designed the study, developed the methodology and wrote the manuscript; A.V.O.T. collected the data and performed the analysis; A.V.A. supervised the data analysis; V.V.E.G. and D.E.G. contributed to paper write up.

\section{Acknowledgements}

This paper was extracted from a master's in engineering thesis undertaken at Universidad Autonoma de Chihuahua. Our sincere appreciation goes to the Consejo Nacional de Ciencia y Tecnologia and to the Facultad de Ingenieria for providing the scholarship and financial support for this programme, respectively.

\section{Conflicts of Interest}

The authors declare no conflicts of interest regarding the publication of this paper. 


\section{References}

[1] Alarcón-Herrera, M.T., Bundschuh, J., Nath, B., Nicolli, H.B., Gutierrez, M., Reyes-Gomez, V.M., Nuñez, D., Martín Domínguez, I.R. and Sracek, O. (2013) Co-Occurrence of Arsenic and Fluoride in Groundwater of Semi-Arid Regions in Latin America: Genesis, Mobility and Remediation. Journal of Hazardous Materials, 262, 960-969. https://doi.org/10.1016/j.jhazmat.2012.08.005

[2] Secretaría de Salud (1994) NORMA Oficial Mexicana NOM-127-SSA1-1994. Last Published Amendment DOF 03-02-1995.

[3] Secretaría de Salud (1995) NOM-041-SSA1-1993. Bottled Water Sanitary Specifications.

[4] Vithanage, M. and Bhattacharya, P. (2015) $\mathrm{CO}_{2}$ Sequestration, Biofuels and Depollution, Vol. 5. Springer, Berlin.

[5] Soto-Rojas, A.E., Ureña-Cirett, J.L. and Martínez-Mier, E.D.L.A. (2004) A Review of the Prevalence of Dental Fluorosis in Mexico. Revista Panamericana de Salud Publica, 15, 9-18. https://doi.org/10.1590/S1020-49892004000100003

[6] Betancourt-Lineares, A., Irigoyen-Camacho, M.E., Mejía-González, A., Zepeda-Zepeda, M. and Sánchez-Pérez, L. (2013) Prevalencia de fluorosis dental en localidades mexicanas ubicadas en 27 estados y el D.F. A seis años de la publicación de la Norma Oficial Mexicana para la fluoruración de la sal. Revista de Investigación Clínica, 65, 237-247.

[7] Olivas Baca, A.C. (2015) Aspectos geológicos del flúor y su presencia en acuíferos del Estado de Chihuahua. Bachelor Thesis, Universidad Autónoma de Chihuahua, Chihuahua.

[8] González-Horta, C., Ballinas-Casarrubias, L., Sánchez-Ramírez, B., Ishida, M.C., Barrera-Hernández, A., Gutiérrez-Torres, D., Zacarias, O.L., Saunders, R.J., Drobná, Z., Mendez, M.A., García-Vargas, G., Loomis, D.L., Stýbo, M. and García-Vargas, G. (2015) A Concurrent Exposure to Arsenic and Fluoride from Drinking Water in Chihuahua, Mexico. International Journal of Environmental Research and Public Health, 12, 4587-4601. https://doi.org/10.3390/ijerph120504587

[9] Precoma Mojarro, A.Y. (2007) Caracterización Hidrogeoquímica y Presencia de Flúor en la Porción Noroeste del Estado de Chihuahua, México. Master's Thesis, Universidad Autónoma de Chihuahua, Chihuahua.

[10] Bencomo Calderón, M. (2013) Comportamiento del arsénico mediante un modelo hidrogeoquímico en el acuífero Meoqui-Delicias. Master's Thesis, Universidad Autónoma de Chihuahua, Chihuahua.

[11] Ruiz-Payan, A., Ortiz, M. and Duarte-Gardea, M. (2005) Determination of Fluoride in Drinking Water and in Urine of Adolescents Living in Three Counties in Northern Chihuahua Mexico Using a Fluoride Ion Selective Electrode. Microchemical Journal, 81, 19-22. https://doi.org/10.1016/j.microc.2005.01.017

[12] Sala, E.C. and García, P.B. (2013) Odontologia preventiva y comunitaria+ student consult en español. Elsevier Health Sciences.

[13] Secretaría de Salud (2003) Manual para el Uso de fluoruros dentales en la República Mexicana.

[14] Molina Frechero, N., Sánchez Pérez, L., Castañeda Castaneira, E., Oropeza Oropeza, A., Gaona, E., Salas Pacheco, J. and Bologna Molina, R. (2013) Drinking Water Fluoride Levels for a City in Northern Mexico (Durango) Determined Using a Direct Electrochemical Method and Their Potential Effects on Oral Health. The Scientific World Journal, 2013, Article ID: 186392. https://doi.org/10.1155/2013/186392 
[15] World Health Organization (2013) Oral Health Surveys: Basic Methods. World Health Organization, Geneva.

[16] Hiremath, S.S. (2011) Textbook of Preventive and Community Dentistry. Elsevier India, Gurgaon.

[17] Secretaría de Salud (2011) Perfil Epidemiológico de la Salud Bucal en México 2010.

[18] Bünsow García, A. (2015) Evaluación de la severidad de fluorosis dental en niños de 12 a 14 años en tres sectores de la ciudad de Delicias, Chihuahua tomando en cuenta género y pieza dental. Bachelor Thesis, Universidad Autónoma de Chihuahua, Chihuahua.

[19] Google Earth (2020) “Julimes” $28^{\circ} 23.412^{\prime} \mathrm{N}$ and $105^{\circ} 25748^{\prime}$ W. Google Earth, March 2020 . 